\title{
極超音速旅客機による輸送ネットワークの初期検討*1 Preliminary Study on a Transportation Network of a Hypersonic Airliner
}

\author{
上 野 篤 史 ${ }^{* 2, * 3} \cdot$ 鈴木 宏二郎*2 \\ Atsushi Ueno and Kojiro Suzuki
}

Key Words : Hypersonic Airliner, Operational Convenience, Transportation Network

\begin{abstract}
The commercial success of a hypersonic airliner is discussed from a viewpoint of its operational convenience. In the hypersonic regime, a lift-to-drag ratio is generally small due to a large wave drag, which results not only in small cruising range but also in an operational inconvenience. To overcome this drawback, we propose a transportation network with multiple hypersonic airliners. The analysis of the operation diagram demonstrates that the travel time of passengers can be significantly reduced in the absence of the arrival and departure in late evening or early morning thanks to the combination of the high flight velocity and flexible network operation, even if the range of the hypersonic transport is limited to $7,330 \mathrm{~km}$. Consequently, the network operation will greatly enhance the potential of the hypersonic aircraft for future high-speed global transportation system.
\end{abstract}

\section{1. は じめ に}

近年，極超音速機に関する研究開発の機運が高まってお り, その中でもこれを旅客機に適用する研究が欧州 11 , 及 び，日本2）で行われている，極超音速旅客機が商業的に成 功するためには, 環境適合性に優れている必要があること に加え, 運用面において既存遷音速旅客機や将来の超音速 旅客機に対する利点を有している必要がある. 現状の極超 音速旅客機の研究は推進系統や空力形状といった機体要素 に主眼が置かれており, 環境適合性や運用に関する研究が 十分とは言えない. 本論文は後者に着目し, 極超音速旅客 機の運用面における利点を明らかにすることを主題とした. 旅客機の運用を検討する際, 特に航続距離が重要と言え る. Breguetの推算式 ${ }^{3)}$ に従うと, 航続距離は巡航揚抗比 と巡航速度に比例し, 燃料消費率に反比例する。超音速旅 客機として活躍したコンコルドは, 既存遷音速旅客機と比 べて巡航速度が高いものの, 造波抵抗のために巡航揚抗比 が低く，また，一般的にマッハ数が高くなるほど燃料消費 率が悪化することから航続距離が短いという欠点があった. これは極超音速旅客機でも同様であり, 著者らは, コンコ ルドと同程度の機体規模（機体長 $60 \mathrm{~m}$, 旅客数 80 名）で液 体水素を燃料とする極超音速旅客機（巡航マッハ数 5) を対 象とした最適設計を実施し, 航続距離がコンコルドのそれ とほほ同等にとどまることを示した ${ }^{4)}$ 。このように, 極超音 速旅客機には航続距離が短いという久点があるため, これ

\footnotetext{
*1 (C) 2009 日本航空宇宙学会

平成 21 年 3 月 14 日原稿受理

*2 東京大学大学院新領域創成科学研究科先端エネルギー工学専攻

*3 現 宇宙航空研究開発機構
}

をいかにして克服するかが運用面における利点を示す上で 重要となる。これに対し著者らは, 複数の極超音速旅客機 により世界の主要都市を結ぶ輸送ネットワークを構築する ことが有効と考えている。つまり, 複数の機体による輸送 ネットワークを対象として運用面の評価を行うことで, 機 体単機では航続距離が短いといった欠点が打ち消され, 極 超音速という高い速度性能を十分に活かすことが可能とな り，これにより遷音速旅客機や超音速旅客機では実現不可 能な利点が得られると考えている。

本論文では，文献 4) に基づく前提条件を考慮して極超音 速旅客機による輸送ネットワークを構築し, 運用面の評価 を行った。

\section{2. 前 提 条 件}

輸送ネットワークの構築のために設定した前提条件は航 続距離と滑走路長の 2 点であり, それぞれ文献 4)に基づき $7,330 \mathrm{~km}, 3,000 \mathrm{~m}$ とした. 前者は $10 \%$ 程度の予備燃料を 考慮したものである. 後者は大部分の既存国際空港で運用 可能であることを意味する。

輸送ネットワークの運用検討のために設定した前提条件を 以下に示す. 東京-ブリュッセル, 東京一ニューヨーク, ニュー ヨークーブリュッセルの 3 路線を対象とした。 なお，東京か らブリュッセルへ向かう便についてはロシアを経由するルー トが存在するが，ここではニューヨークへ向かう便との接 続を考慮し，アンカレッジを経由することとした（第 1 図 参照)。運用機体数を 3 とし, 機体 A，B，C はそれぞれ東 京，アンカレッジ，ブリュッセルを母港とした。飛行時間 (巡航マッハ数 5) はアンカレッジーブリユッセル路線を 110 分とし，これ以外の路線は 90 分とした。なお，飛行時間 
には上昇加速，降下減速に必要な時間（それぞれ 20 分 4$)$ ) が含まれる。ターンアラウンド時間，乗り継ぎ時間をそれ ぞれ 90 分 (液体水素燃料補給時間を含む), 60 分とした。 これらは既存遷音速旅客機を参考として設定したが，極超 音速飛行中に上昇した機体表面温度の泠却時間を踏まえて 今後精査する必要があると考えられる。陸上極超音速飛行 について，その可否はソニックブーム強度に依存する。文 献 4) の極超音速旅客機のソニックブーム強度は, 修正線形 理論に基づく First-Cut 法によると約 1psf である。更に, 修正線形理論は極超音速域ではソニックブーム強度を過大 評価することが CFD 解析により示されている5)。これによ りソニックブーム強度が現状の低減目標である $0.5 \mathrm{psf}$ 以下 となるかは今後の検討が必要であるが, ここでは陸上極超 音速飛行を許容した。 また, 運用上の制約条件として, 深 夜・早朝時（23 時から 5 時）の発着がないこと, 母港にお いて整備・点検の時間を確保すること, 前記 3 路線を 1 日 1 便設定すること，を設定した。

\section{3. 結果と考察}

3.1 輸送ネットワークの構築 $7,330 \mathrm{~km}$ の航続距離で 実現可能な輸送ネットワークを第 1 図に示す. 実線は陸上 極超音速飛行を含まない路線で，点線はこれを含む路線を 示す. 本論文では陸上極超音速飛行を許容するとしたが, 仮 にこれを許容しないとしても, 東京からアンカレッジ経由 で北米西海岸や欧州への飛行が可能であり, また, 東南ア ジアや豪州への直接飛行が可能である。このように, 航続 距離が $7,330 \mathrm{~km}$ であれば, 各地域 (北米, 南米, 欧州, 口 シア, 中東, アジア, 豪州, アフリカ) の代表的な都市を 結ぶ輸送ネットワークが実現可能である.

3.2 輸送ネットワークの運用第 1 図で示した輸送ネッ トワークのうち, 前提条件で示した 3 つの路線を対象とし た 3 機の機体による運用の検討結果を第 2 図に示す. 図中 の数值は時間であり, 網掛け部は深夜・早朝時に対応して いる。(1)が東京一ニューヨーク，(2)が東京ーブリュッセル，(3) がニューヨークーブリュッセルの路線で，それぞれ，1 日 1 便設定されている。機体 A は東京一アンカレッジ間を 2 往 復して整備に入る。機体 B はアンカレッジーニューヨーク 間を 1 往復して整備に入る。機体 $\mathrm{C}$ はブリュッセルーアン カレッジ間，及び，ブリュッセルーニューヨーク間をそれぞ れ 1 往復して整備に入る。この場合, 機体の年間運用時間 が既存遷音速旅客機よりも大幅に少ないため，運行経費の 観点を考慮に入れた検討が今後必要と考えられる。

東京からニューヨークに飛びたい乗客はまずは機体 A に 乗り, アンカレッジで機体 B に乗り換えることとなる。こ うすることで, 東京一ニューヨーク間の飛行時間は 4 時間と なり，既存遷音速旅客機に対し飛行時間を約 $70 \%$ 短縮する ことが可能となる。また，東京からブリュッセルに飛びた い乗客は，機体 A から C に乗り継ぐこととなる。このよ うに, 3 機の機体でネットワークを運用することで, 単機 の性能としては既存遷音速旅客機よりも航続距離が短いと いった久点が打ち消され, 大幅に飛行時間が短縮されるこ

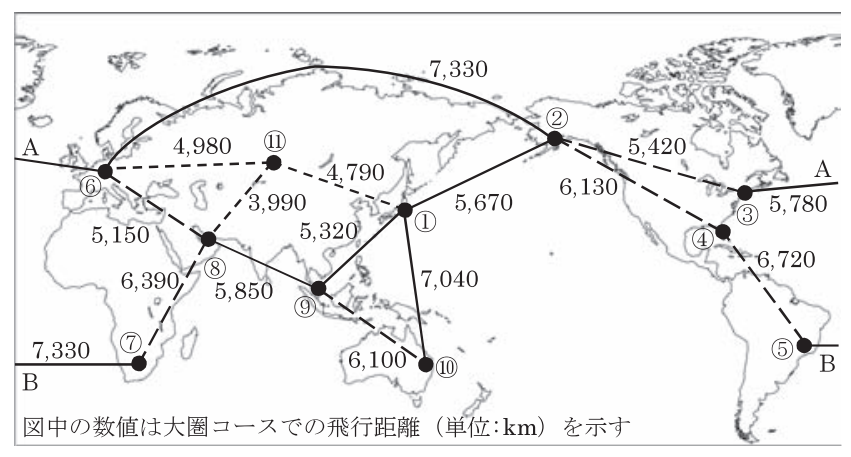

第 1 図 極超音速旅客機による輸送ネットワーク

(1)東京国際空港，(2)アンカレッジ国際空港，(3)JFK 国際空 港，(4)オーランド国際空港，(5)グアルーリョス国際空港，(6) ブリュッセル国際空港，(7)ヨハネスブルグ国際空港， 8)ドバ イ国際空港，(9)ャンギ国際空港，(10ブリスベン国際空港， (11)ノヴォシビルスク空港.

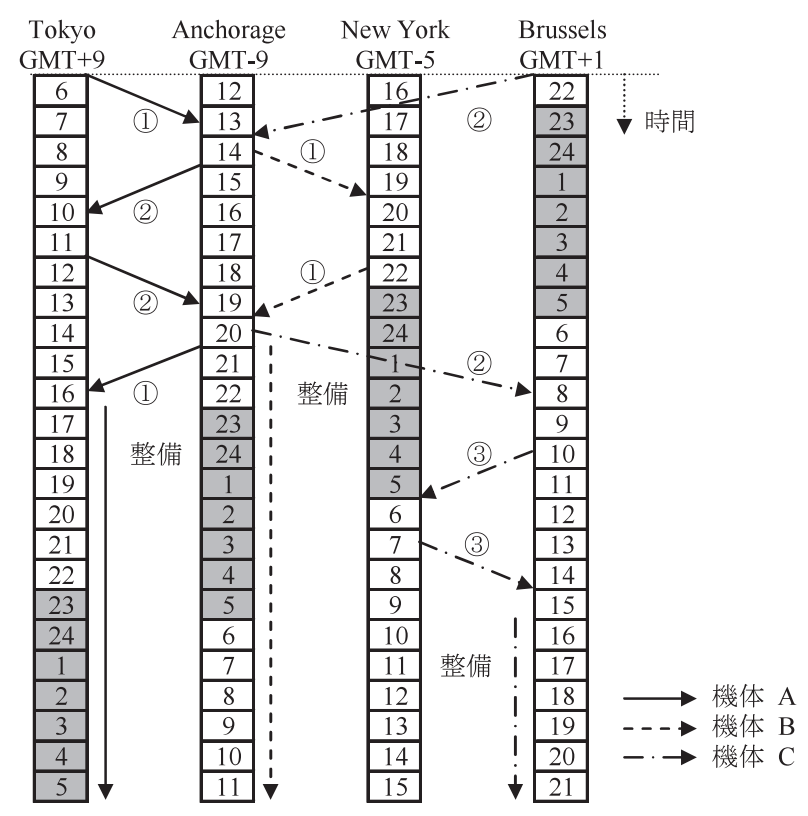

第 2 図 輸送ネットワークの運用

ととなる. 従って, 飛行時間の短縮が極超音速旅客機の運 用面における利点と言える。

しかし，利点はこれだけにとどまらない。代表的にマッ ハ 2 の超音速旅客機で本ネットワークを運用した場合にど うなるかを検討する。巡航マッハ数低下のために飛行時間 がマッハ 5 の場合の 2.5 倍になると考える。このとき，6 時 に機体 $\mathrm{A}$ が東京を離陸し，アンカレッジで機体 B に乗り 継いでニューヨークへ飛行した場合，ニューヨーク着が深 夜の 23 時 30 分となる。 また，マッハ 5 の場合には東京一 ニューヨーク間の往復が可能であるが, マッハ 2 の場合に は前述のように機体 B のニューヨーク着が深夜となるため, ニューヨークから東京に戻る便が成立しない. よって，速 い速度で飛行することで, 深夜・早朝時の発着の回避が容 易となり，ネットワーク運用の柔軟性が増すと言える。こ れは極超音速旅客機を運行する側から見れば大きな利点と なると考えられる. 
以上のように，極超音速旅客機により輸送ネットワーク を構築し運用することで, 飛行時間が短縮されるという乗 客から見た利点に加え, 運用の柔軟性が増すといった運行 側の利点も発生すると言える。

\section{4. 結 論}

極超音速旅客機の運用面における利点を評価し，以下の 結論を得た。

1) 航続距離が短い極超音速旅客機を単機で運用するのは 好ましくない。この欠点の解消に対して複数の機体による 輸送ネットワークを運用することが有効であり，これによ り高い速度性能が有効利用可能となる。

2) 輸送ネットワークにより既存遷音速旅客機や将来の超 音速旅客機と比べて目的地により早く到着するといった乗 客側から見た利点が得られる。
3) 高い速度性能により深夜・早朝時の発着を避けた運行 設定が容易となるといった運行側から見た利点が得られる.

\section{参 考 文 献}

1) Steelant, J.: Achievements Obtained for Sustained Hypersonic Flight within the LAPCAT Project, AIAA Paper 2008$2578,2008$.

2) 宇宙航空研究開発機構航空プログラムグループ極超音速機研究委 員会: 極超音速機の研究開発構想, JAXA-SP-06-025, 2007.

3) Raymer, D. P.: Aircraft Design: A Conceptual Approach, 3rd ed., AIAA Education Series, AIAA, Reston, VA, 1999, p. 21.

4) 上野篤史: 極超音速旅客機の空力形状最適化と航続性能向上に関 する研究, 東京大学博士論文, 2008 .

5）深川寛也, 上野篤史, 綿貫忠晴, 今村 宰, 鈴木宏二郎: 極超音速 ソニックブームの圧力波形輸送に関する研究, 第 41 回流体力学 講演会/航空宇宙数值シミュレーション技術シンポジウム, 2009 . 